\title{
Seguridad Alimentaria: Juégatela seguro con los huevos $^{1}$
}

\author{
Linda B. Bobroff y Jennifer Hillan²
}

Los huevos frescos pueden contener bacterias que podrían causar una enfermedad llamada salmonelosis. Esta enfermedad causada por alimentos provoca vómito y diarrea. Esta puede ser severa y hasta podría ser fatal para los adultos de mayor edad. Reduzca el riesgo de contraer esta enfermedad al seguir estas pautas.

\section{Use los huevos en una manera}

\section{segura}

- No compre huevos quebrados.

- Compre huevos antes de la fecha de vencimiento en el cartón y úselos en las próximas 3 a 5 semanas.

- Refrigere los huevos crudos después de comprarlos. Manténgalos en el cartón original en la parte más fría del refrigerador.

- Cocine los huevos hasta que la yema y la clara estén firmes; si los huevos son pasteurizados, no es necesario.

- Cocine las cacerolas y otros platos que contienen huevos a $160^{\circ} \mathrm{F}$.

- Use huevos pasteurizados en algunas recetas que piden huevos crudos, tales como helado hecho en casa, aderezo de ensalada César o salsa holandesa, para asegurar la seguridad del plato.

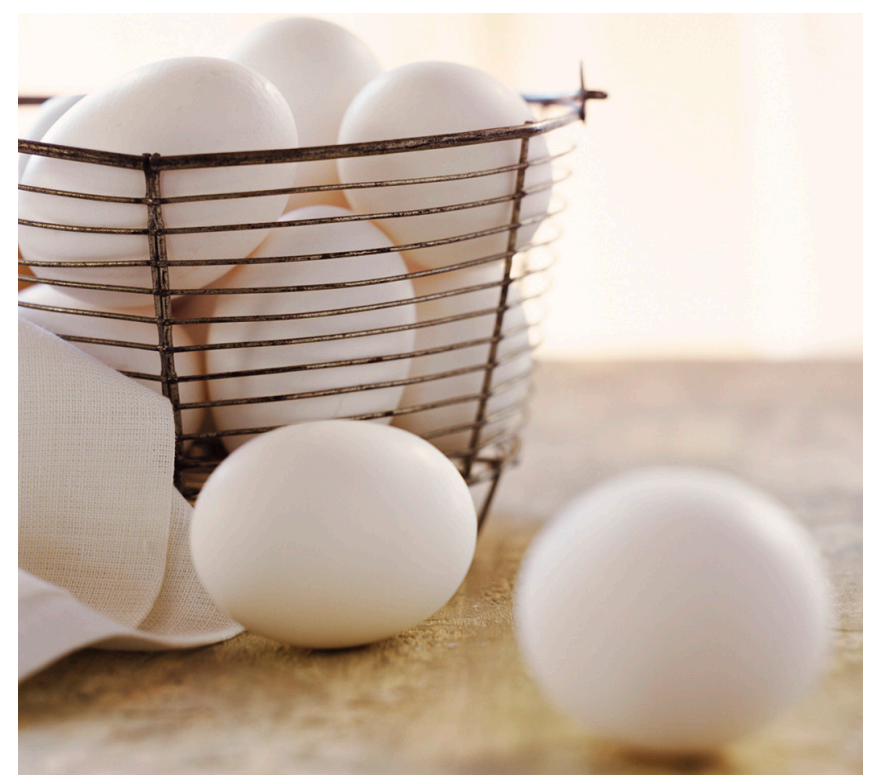

Figura 1. Compre huevos antes de la fecha de vencimiento imprimida en el envase. Guardelos en la caja de cartón en la parte más fría del refrigerador por no más de 5 semanas.

Credits: Digital Vision

\section{¿Y qué tal las sobras?}

- Consuma los huevos cocidos en menos de una semana después de haberlos cocido.

- Refrigere inmediatamente las sobras de comida que contiene huevo y úselos en menos de 3 días.

- Recaliente las sobras de comida que contiene huevo a $165^{\circ} \mathrm{F}$ antes de consumirlas.

1. Este documento es FCS8635-Span (the English version of this document is Food Safety: Play It Safe with Eggs (FCS8635)), uno de una serie del Departamento de Ciencias de la Familia, la Juventud y la Comunidad, UF/IFAS Extensión. Publicado: mayo 2010. Revisado febrero 2018. Traducido del Inglés por Rafael Arango y Claudia Peñuela. Por favor visite el sitio en la web en EDIS http://edis.ifas.ufl.edu.

2. Linda B. Bobroff, PhD, RDN, profesora, Departamento de Ciencias de la Familia, la Juventud y la Comunidad; y Jennifer Hillan, MSH, RD, LD/N, anterior educadora de nutrición ENAFS; UF/IFAS Extensión, Gainesville, FL 32611. 